Zakir: epiraf na statule Jerach-'Azar.

Jerach-'Azar: epigraf na statule.

Bod'el - imię to pojawia się w r. 701 za czasów Sancheryba, następnie za czasów Asarchaddona (681-669) i Assurbanipala.

'Amminadab I: cylinder C Assurbanipala w r. 667 przed n. Chr.

N.........., syn 'Amminadaba.

'Amminadab II: butelka z Tell Siran.

'Hissal'el - syn Amminadaba.

'Amminadab III, syn Hissal'ela.

Ba'alis; ok. r. 580 przed Chr., Jr 40, 14, czasy Nabuchodonozora II.

Wieden

Ks. NORBERT MENDECKI

KOMENTARZE -REFLEKSJE - MATERIAŁY DUSZPASTERSKIE

Ks. Szymon Fedorowicz

\title{
PRZEKAZ WIARY A WŁOŻENIE RAK W OBRZĘDACH KATECHUMENATU
}

\section{FORMA OBRZEDU}

Gest włożenia rąk występuje w obrzędach katechumenatu wielokrotnie (rytuał mówi o nim aż 17 razy, ponadto w przypadku egzorcyzmów i błogosławieństw może być często powtarzany, OCHWD 109, 119). Jest więc znakiem powszechnie stosowanym w liturgii. Wywodzi się z bardzo odległej tradycji biblijnej, a w ciągu długich wieków nabrał rozmaitych znaczeń.

Naprzód trzeba zaznaczyć, że włożenie lub nałożenie rąk (impositio manus) było i jest wykonywane na kilka sposobów. W Piśmie Świętym w większości przypadków ręce wkładano na głowę, a spośród nich niektóre wydają się zawierać jej bezpośrednie dotknięcie.

${ }^{20} \mathrm{~F} . \mathrm{Z}$ a y a d i n e, Inschriften, dz. cyt., 147.

${ }^{21}$ F. Z a y a d i n e, Die Zelt der Königreiche Edom, Moab und Ammon, [w:] Der Königs Weg, dz. cyt., 120. 
Gest ten wykonywano jedną ręką lub dwoma ${ }^{1}$. Ta swoboda co do formy zewnętrznej świadczy o tym, że nie przywiązywano wagi do jego strony zjawiskowej, ale że istota i treść gestu tkwi w czym innym ${ }^{2}$. Tak jest również $w$ naszych Obrzędach. Np. podczas egzorcyzmu sprawowanego w ramach skrutyniów: najpierw, jeśli warunki pozwalają, celebrans kładzie w milczeniu ręce na każdego wybranego. Potem wyciągając ręce nad wybranymi, celebrans mówi dalej...”. A zatem znaczenie szczegółowe określa zawsze specjalna formuła słowna, która towarzyszy włożeniu rąk ${ }^{3}$.

\section{WŁOŻENIE RĄK JAKO PRZEKAZYWANIE}

Gest sam w sobie oznacza przekazywanie drugiej osobie coś $\mathrm{z}$ siebie samego, coś z tego, co się samemu posiada lub czym się jest, a na co konkretnie właśnie wskazują słowa. Jest to znak rzeczywistego, najgłębszego dotknięcia samej osoby, a to stąd, że ręce są, obok słów, powszechnym i wyrazistym środkiem komunikacji międzyludzkiej. W Piśmie Świętym ręka jest symbolem mocy w ogóle (Wj 14, 21.27), a także symbolem Bożej mocy, która działa przez ludzi i ludzkie ręce ${ }^{4}$. Dlatego znak obrzędu liturgicznego jest czytelny, a przez to, jako nośnik konkretnej treści o charakterze zbawczym, pełni swą ewangelizacyjną funkcję.

Już w Starym Testamencie obrzęd włożenia rąk ma kilka znaczeń $^{5}$. Przede wszystkim jest znakiem przekazywania błogosławieństwa ( $R d z$ 48, 14-15). Również Jezus posługuje się tym gestem, gdy błogosławi dzieci (Mk 10, 16). I to znaczenie weszło w liturgiczną praktykę Kościoła, także w odniesieniu do procesu wtajemniczenia. Nałożenie ręki było pierwszym konkretnym rytem katechumenalnym, ale zarazem najbardziej typowym elementem inicjacji ${ }^{6}$. Po raz pierwszy jako błogosławieństwo wstępuje w relacji św. Hipolita, we-

${ }^{1}$ F. C a b r o l, Imposition des mains, DACL, t. VII, s. 398; P. G a l$\mathrm{t}$ i e r, Imposition des mains, DTC, t. VII, s. 1335.

${ }^{2}$ Objaśnienie do numerów 164, 171, 178. Podobnie jest przy błogosławieństwach, zob. nr 119. P. Galtier czyni taką uwagę: „Jeśli nałożenie rąk oznacza często przykładanie materialne i fizyczne, ryt sam w sobie wcale nie zawiera tego zetknięcia", op. cit., s. 1336.

${ }^{3}$ F. C a b r o l, op. cit., s. 396; J.-B. B r u n o n, Wtożenie rak, STB, s. 1053.

${ }^{4}$ J.-B. B r u n o n, op. cit., s. 1052.

${ }^{5}$ L. Boyuer podaje taką definicję: „Nałożenie - ryt zasadniczo interpretowany jako przekazanie daru lub władzy. Wydaje się, że jego pierwotny sens był raczej wzięciem w posiadanie, skąd wywodziłby się sens przyjęcia do wspólnoty", Dictionnaire théologique, Tournai 1963, s. 328 (dalej: DT).

${ }^{6}$ B. M o k r z y c k i, op. cit., s. 85. 
dług którego udzielane było ono katechumenom przez katechetę po modlitwie kończącej katechezę, właśnie prze nałożenie ręki ${ }^{7}$. Taki też charakter ma ten gest $\mathrm{w}$ dzisiejszych obrzędach wtajemniczenia, które przewidują na zakończenie Liturgii Słowa Bożego, a także spotkania katechetycznego, udzielanie błogosławieństwa przez wyciągnięcie rąk nad głowami katechumenów (oraz ewentualnie przez nałożenie ręki) i odpowiednią modlitwę (OCHWD 119, 121-124).

\section{WŁOŻENIE RĄK JAKO AKT POŚWIĘCENIA BOGU}

Innym znaczeniem starotestamentowym obrzędu jest poświęcenie, które wyłącza jakieś stworzenie ze zwykłego użytku i przeznacza Bogu. On sam je wybiera dla spełnienia nowych funkcji w ramach planu zbawienia. Taki sens miało naznaczenie Jozuego na przewodnika narodu wybranego po Mojżeszu, który z Bożego polecenia przekazał mu „część swojej godności” przez włożenie rąk (Lb 27, $18-23)^{8}$. Ta sama idea przyświecała zastosowaniu tego gestu w obrzędzie przyjęcia do katechumenatu. Skoro do istoty katechumena należało być już własnością Chrystusa, dlatego tradycyjny gest brania $\mathrm{w}$ posiadanie łatwo zaaplikowano do tego obrzędu, który w ten sposób prowadzi do spotkania z Bogiem.

Synod w Elwirze (ok. 350 r.) zastosował prawdopodobnie tylko gest włożenia rąk w obrzędzie przyjęcia pogan do katechumenatu; podobny zwyczaj istniał również w Galii (Synod w Arles w 314 r.) $)^{9}$. Najczęściej jednak obrzęd zawierał dwa towarzyszące sobie gesty: naznaczenie krzyżem czoła oraz włożenie rąk. Związek, a nawet ich identyfikacja pojawia się już w II wieku. Świadczy o tym pseudo Epistola apostolorum, w którym mowa jest o nawróceniu św. Pawła, odzyskującego wzrok na skutek naznaczenia krzyżem oczu, a nie jak jest w Dziejach Apostolskich $(9,12.17)$, przez nałożenie rąk ${ }^{10}$. To połączenie najwyraźniej dokonało się w rytach bierzmowania i przetrwało do naszych czasów.

${ }^{7}$ Tradycja Apostolska 18; B. M o k r z y c k i, op. cit., s. 85. Tak też mają Konstytucje Apostolskie VII, 39, 4; V. S a x e r, op. cit., s. 227. W. S c h e n k, Liturgia..., op. cit., s. 27. Jungmann zwraca uwagę, że: „Podczas, gdy dziś udzielamy błogosławieństwa kreśląc znak krzyża, wówczas działo się to przez nałożenie rąk, symbolizujące, że błogosławieństwo przekazywało coś z uświęcającej władzy tego, który go udzielał", op. cit., s. 124.

${ }^{8}$ J.-B. B r u n o n, op. cit., s. 1052 . X. L é o n-D u f o u r rozumie ten obrzęd jako „ryt inicjacyjny”, Stownik Nowego Testamentu, Poznań 1986, s. 544 (dalej: SNT).

${ }_{9}$ G. B a r e il l e, op. cit., s. 1972; P. d e Pu n i e t, op. cit., s. 2600.

${ }^{10} \mathrm{P}$. G a l t i e r, op. cit., s. 1337. 
Papież św. Gelazy mówi o wprowadzeniu kandydata do katechumenatu przez konsygnację, albo włożenie $\mathrm{rąk}^{11}$. O konsygnacji jako pierwszym obrzędzie przyjęcia do katechumenatu wspomina diakon Marek w Żywocie św. Porfiriusza ${ }^{12}$. Wreszcie wyraźne świadectwo wspólnego występowania obu gestów obrzędzie przyjęcia daje św. Augustyn, nadmieniając o dołączonej do nałożenia rąk modlitwie $^{13}$. Nieco później, w VI wieku, świadkiem połączenia tych (i innych) rytów w jednym obrzędzie bezpośrednio poprzedzającym samą ceremonię chrztu będzie Pseudo Dionizy ${ }^{14}$.

W aktualnych obrzędach wtajemniczenia dorosłych gest nałożenia rąk pojawia się w ramach uroczystego przyjęcia do katechumenatu jeden raz. Ma on jednak zdecydowanie charakter odesłania katechumenów, przewidzianego na zakończenie modlitwy powszechnej, po której sprawuje się Eucharystię już bez ich udziału ${ }^{15}$. O takim zastosowaniu nałożenia rąk w starożytności świadczy św. Hipolit ${ }^{16}$.

\section{WŁOŻENIE RĄK JAKO AKT UZDROWIENIA}

Jezus wiele razy czynił ten gest jako znak uwolnienia, bądź uzdrowienia. Kładąc ręce na chorych przywracał im zdrowie (Mk 6,5 ) i uwalniał od dolegliwości (Łk 13, 12-13) oraz od wpływu złego ducha ( $\mathrm{kk} 4,40 \mathrm{n}$ ). Ten sens z kolei zawiera się w obrzędach egzorcyzmów, których celem jest uzdrowienie, oczyszczenie duszy i uwolnienie jej spod władzy sił piekielnych. Egzorcyzm oznacza tryumf królestwa Bożego nad szatanem ${ }^{17}$, ale nasz udział w tym zwycięstwie nie jest definitywny. Dlatego obrzęd w ciągu całego procesu inicjacji powtarza się często. Przebiega w ten sam sposób (nałożenie rąk + modlitwa) i tych samych okolicznościach, co wspomniane wcześniej

${ }^{11}$ Ibidem, s. 1316. Autor tak wyjaśnia pojęcie konsygnacji: „odnosi się do znaku krzyża, który co najmniej często łączy się z nałożeniem rąk”, s. 1340.

${ }_{12}^{12}$ P. d e P u n i e t, op. cit., s. 2590.

${ }^{13}$ De peccatorum meritis et remissione, PL 44 176, zob. W. S c h e n k, Liturgia..., op. cit., s. 31. Gdy od VI wieku chrzczono już powszechnie dzieci, przy ich przyjęciu do katechumenatu „kapłan czynił na czole każdego dziecka znak krzyża (...) po czym kładł ręce na głowę dziecka”, s. 38.

${ }_{15}^{14}$ De hierarchia ecclesiastica, PG 3 396A; V. S a x e r, op. cit., s. 459.

${ }^{15}$ OCHWD, objaśnienie do numeru 95, 96, 97. Podobnie postępuje się wobec wybranych (zob. objaśnienia do $\mathrm{nr} 149,150,151$ ), a także w stosunku do poddawanych egzorcyzmom $\mathrm{w}$ ramach skrutyniów (zob. objaśnienia do numeru 164, 171, 178 i numery $165,172,179$ ).

${ }^{16}$ P. G a l t i e r, op. cit., s. 1317. Autor wyjaśnia: „Obrzęd przyjęcia do katechumenatu, nałożenie rąk jest też obrzędem odesłania katechumenów pod koniec tej części mszy, do której zostali dopuszczeni”.

${ }^{17} \mathrm{X}$. L é o n-D u fo u r, SNT, s. 246. 
błogosławieństwa (OCHWD 109, 113-118), ale zwłaszcza podczas przygotowania bliższego katechumenów do chrztu. W starożytności w tym okresie egzorcyzmowano ich codziennie ${ }^{18}$.

Nałożenie rąk w formie egzorcyzmu stosowano w Kościele pierwszych wieków równie dawno jak analogiczne błogosławieństwa. Występowało coraz intensywniej i uroczyściej (na przykład podczas skrutyniów, jak podaje św. Ambroży ${ }^{19}$ ) w miarę zbliżania się katechumenów do chwili najważniejszej - ceremonii udzielania sakramentów wtajemniczenia. Ilustrowało to dobrze trwającą i wzmagającą się walkę z mocami ciemności, aż do ostatecznego zwycięstwa w noc paschalną (ostatni egzorcyzm sprawowany przez biskupa i kąpiel chrzcielna) ${ }^{20}$, a także - od strony negatywnej - uświadamiało to, co człowieka od Boga oddzielało.

\section{WŁOŻENIE RĄK JAKO AKT KONSEKRACJI}

Włożenie rąk w Kościele czasów apostolskich praktykowano jako obrzęd konsekracji, którego sensem było przekazywanie drugiej osobie Bożych darów, a zwłaszcza daru Ducha Świętego (Dz Ap 8, 17) ${ }^{21}$. Ciekawe świadectwo daje św. Cyryl: „Widzisz wszędzie - tak w Starym jak i w Nowym Przymierzu - ten sam symbol. Za czasów Mojżesza Duch był dany przez włożenie rąk, również Piotr udziela Ducha przez włożenie rąk. I na ciebie przyjdzie w chrzcie ta łaska"22. Odnoszący się do neofitów gest oznaczał więc z pewnością sprawowanie sakramentu bierzmowania, uzupełniającego łaske chrztu ${ }^{23}$. Takie znaczenie nałożenia rąk spotykamy u Tertuliana ${ }^{24}$ i nieco później u św. Hipolita ${ }^{25}$. Według św. Augustyna bez tego obrzędu nie można otrzymać Ducha Świętego jako dopełnienie chrztu ${ }^{26}$. Zesłanie darów

${ }^{18}$ Św. C y r y l, op. cit., s. 35; E t e ri a, Pielgrzymka do miejsc świętych, PSP, t. VI, Warszawa 1970, s. 224 . Tak podaje też św. Hipolit w Tradycji Apostolskiej 20. B. M o k r z y c k i, op. cit., s. 88; V. S a x e r, op. cit., s. 114; zob. W. S c h e n k, Liturgia..., op. cit, s. 27.

${ }^{19}$ V. S a x e r, op. cit., s. 342 .

${ }^{20}$ J. D a n i él o u, Bible..., op. cit., s. 35-36.

21 J.-B. B r u n o n, op. cit., s. 1053.

${ }^{22}$ Katechezy, op. cit., s. 255.

${ }^{23} \mathrm{P}$ a w e 1 VI, Konstytucja Apostolska "Divine consortium naturae”, o Sakramencie Bierzmowania, [w:] Obrzędy Bierzmowania, Katowice 1975, s. 11.

${ }^{24}$ De carnis. resurrectione 8; PL 2852 . V. S a x e r, op. cit., s. 131.

${ }^{25}$ Tradycja apostolska, 21; V. S a x e r, op. cit., s. 116; B. M o k r z yc k i, op. cit., s. 99.

${ }_{26}$ Sermo 266, 3-6; PL 38 1225-1227; V. S a x e r, op. cit., s. 394. 
Ducha Świętego jest również treścią modlitwy konsekracyjnej współczesnego obrzędu bierzmowania, którą odmawia celebrans przy jednoczesnym nałożeniu rąk, ale nade wszystko myśl tę wyraża sakramentalna formuła: „Przyjmij znamię Ducha Świętego”, wypowiedziana równocześnie $\mathrm{z}$ gestem położenia prawej dłoni na głowie bierzmowanego i namaszczenia czoła w formie krzyża ${ }^{27}$. Obrzęd w tym (choć nie tylko) znaczeniu jest jednocześnie desygnacją, naznaczeniem do pełnienia konkretnej funkcji w dziele ewangelizacji ${ }^{28}$. Zaangażowanie apostolskie jest bowiem prostą i logiczną konsekwencją nawrócenia, będącego jej owocem. Dzięki temu nieustannie realizuje się Chrystusowe posłannictwo, w którym również katechumeni mają swoją rolę do spełnienia, na co wskazywałby obrzęd włożenia rąk.

\section{WŁOŻENIE RĄK JAKO WZIĘCIE POD OPIEKE}

I wreszcie gest ten może wyrażać wzięcie kogoś pod swoją opiekę i wpływ (OCHWD 147, 162, 169, 176). Taka zapewne była również treść obrzędu przy przyjęciu kandydatów do katechumenatu w starożytności. Tak też postępuje Kościół i dziś, gdy podczas obrzędów przygotowujących do chrztu dzieci „kapłan wkłada rękę na głowę dziecka: Kościół bierze dziecko w swoją opiekę, w swoje posiadanie i prosi Boga o łaskę, by dziecko stało się pożytecznym członkiem Kościoła, wolnym od zła" ${ }^{29}$. To branie w opiekę oznacza również gest położenia ręki rodziców chrzestnych na ramionach wybranych $\mathrm{w}$ trakcie obrzędu wpisania imienia oraz podczas skrutyniów. Kościół powierza kandydatów do chrztu trosce chrzestnych, aby pomogli im dojść do sakramentów świętych (OCHWD 147, 162, 169, 176).

Ewangelizacyjna rola obrzędu nałożenia rąk, który odczytywany jest jako błogosławieństwo, poświęcenie, konsekracja, albo uzdrowienie czy uwolnienie, staje się bardzo wyrazista. Zwłaszcza, gdy konkretny gest jest znakiem widzialnym i zrozumiałym rzeczywistej, ale działającej mocy Bożej, zstępującej na ludzi i sprawiającej dokładnie to, o co Kościół prosi przez wykonywanie obrzędu. Jego wewnętrzna wieloaspektowa treść wskazuje na to, że człowiek wchodzący w zasięg oddziaływania Bożej laski staje się uczestnikiem zbawienia jako daru Boga. A ono przecież jest celem ewangelizacji.

${ }^{27}$ OCHWD 230, 231; Obrzędy Bierzmowania nr 9.

${ }^{28}$ F. C a b r o l, op. cit., s. 399; J.-B. B r u n o n, op. cit., s. 1053.

${ }^{29}$ W. S c h e n k, Liturgia..., op. cit., s. 49. 


\section{ZNACZENIE WRĘCZENIA EWANGELII}

\section{a. Powstanie obrzędu i jego uzasadnienie}

Trzecim charakterystycznym momentem dla obrzędu przyjęcia jest wręczenie katechumenom księgi Ewangelii. Nie ma ono uroczystego wydźwięku. Jedynym elementem podkreślającym zewnętrznie doniosłość tego rytu jest procesjonalne wniesienie księgi Pisma Świętego, złożenie jej na ambonie i okadzenie przed rozpoczęciem liturgii słowa Bożego. Samo wręczanie odbywa się zaraz po homilii wyjaśniającej dopiero co odczytane teksty (OCHWD 93). Jest to pozostałość po dawnym obrzędzie przekazywania Ewangelii (traditio Evangeliorum), który wraz z dwoma innymi - przekazanie Symbolu wiary i Modlitwy Pańskiej - stanowił ważną część bezpośredniego przygotowania katechumenów do chrztu.

Pochodzenie tego obrzędu jest bardzo odległe, choć pojawił się on stosunkowo późno, bo dopiero w VI wieku, czyli w okresie, kiedy klasyczny katechumenat przeminął nieodwołalnie, a pozostałości tej zasłużonej instytucji ulegały stopniowej degradacji. Był to więc nowy obrzęd przedchrzcielny, potwierdzony po raz pierwszy przez Sakramentarz Gelazjański, a który wywodził się ze środowiska Kościoła rzymskiego ${ }^{30}$.

W tym czasie zmieniła się zasadniczo sytuacja Kościoła. W krajach, które zaczęły powstawać na gruzach imperium rzymskiego, chrześcijaństwo zapuściło już mocne korzenie. W katechumenacie było już coraz mniej dorosłych, praktyka chrztu dzieci stała się masowa, a w centrum Kościoła, Rzymie prawie wyłączna. Katechumenat dorosłych ulegał systematycznej redukcji, a w końcu całkowicie zaniknął. Zachowano formy obrzędowe, nawet je rozbudowano, gdyż $\mathrm{w}$ odniesieniu do dzieci miało to sens oraz harmonizowało dobrze z teologiczną myślą o doniosłości roli Bożej łaski w drodze człowieka do wiary i zbawienia. Stąd wynika rola, jaką przypisywano skrutyniom: „aby dobrze pokazać, że aplikowały one kandydatom przemieniające działanie Boga"31.

Dawna katecheza katechumenalna, dająca przygotowanie doktrynalne i pouczenie w dziedzinie moralności chrześcijańskiej, stała się odtąd bezużyteczna, gdyż nie mogła być kierowana do małych dzieci. Dlatego została zastąpiona obrzędem przekazywania czterech Ewangelii. Mamy tutaj dobry przykład procesu rytualizacji katechezy i katechumenatu w ogóle ${ }^{32}$.

Formuła wypowiadana podczas wręczania księgi Ewangelii brzmi w dzisiejszym rytuale następująco: „Przyjmij Ewangelię Je-

${ }^{30}$ V. S a x e r, op. cit., 612; B. M o k r z y c k i, op. cit., s. 175.

${ }^{31}$ R. B é r a u d y, op. cit., s. 522 .

${ }^{32}$ Ibidem, s. 525; V. S a x e r, op. cit., s. 630. 
zusa Chrystusa, Syna Bożego, abyś Go lepiej poznał i wierniej naśladował" (OCHWD 93). Te krótkie słowa wyraźnie wskazują na dwa główne cele starożytnej katechezy przedchrzcielnej: poznanie prawd wiary i przyswojenie postawy ucznia Chrystusowego ${ }^{33}$. Obecnie zatem nie straciły one na aktualności. Są też najgłębszym sensem obrzędu, który stojąc na progu procesu przygotowania do chrztu ma wskazać katechumenom drogę i właściwy kierunek, prowadzący do pełnego spotkania z Bogiem w sakramentach. A więc ich treść ewangelizacyjna, a stąd i rola, są bardzo charakterystyczne.

Wprowadzając obrzęd we wczesnym średniowieczu wskazywano na źródło, z którego należy czerpać, aby rozwijać wiarę dynamicznie. Troska o dojrzewanie duchowe dziecka była w ten sposób powierzona chrześcijańskim rodzicom. Karmiąc je ewangelicznymi wartościami zobowiązywali się oni do przekazania mu swojej wiary i do prowadzenia go do wspólnoty Kościoła. Natomiast dorosły katechumen czasów dzisiejszych, mając w ręku taki instrument, może w sposób niezawodny iść drogą wiary i ewangelii na spotkanie z Chrystusem w sakramencie chrztu.

\section{b. Symbolika obrzędu}

Przekazanie Ewangelii było obrzędem uroczystym i bardzo rozbudowanym. Ceremonia rozpoczynała się procesjonalnym niesieniem czterech ksiąg Ewangelii i umieszczeniem ich na czterech rogach ołtarza. Następnie papież (ponieważ przekazanie Ewangelii sprawowano wyłącznie w Rzymie) zwięźle wyjaśniał zebranym znaczenie świętych tekstów, ich pochodzenie oraz autorstwo. Ewangelie to dzieła Boże, to Dobra Nowina Pana naszego Jezusa Chrystusa. Wywodzi się natomiast $z$ tego, co głosi i ukazuje, że mianowicie ten, który zapowiedziany był przez proroków przyszedł w ciele. A imiona tych, którzy napisali ewangelie to: Mateusz, Marek, Łukasz i Jan, których wyjaśniający uważał za zapowiedzianych przez proroka Ezechiela w czterech tajemniczych znakach: człowieka, lwa, wołu i orła (Ez 1, 5nn; por. Ap 4, 7) . $^{34}$.

Cały ten wykład - expositio Evangeliorum - miał prowadzić, jakby do otwarcia uszu kandydatów (apertio aurium) na słuchanie słowa Bożego i Bożej prawdy. To bowiem było celem ich przybycia na spotkanie (ut aures vobis aperiantur). W ten sposób dokonywało się

${ }^{33}$ Św. A u g u s t y n, Wiara i uczynki [w:] Pisma katechetyczne, Warszawa 1952 , s. 180.

${ }^{34}$ M. R i g h e t t i, Manuale di storia liturgica, Milano 1959, t. IV, s. 78; V. S a x e r, op. cit., s. 599. Por. B. M o k r z y c k i, op. cit., s. 183; W. S c h e n k, Liturgia..., op. cit., s. 38 . 
również pierwsze dla nich otwarcie (niejako) księgi słowa Bożego. Katechumen miał być przez ten obrzęd wprowadzony w poznanie czterech Ewangelii, narzędzi chrześcijańskiego prawa (instrumenta legis divinae), co dla przekazu wiary miało znaczenie kluczowe ${ }^{35}$.

To śmiałe wykorzystanie symboliki wyjętej $\mathrm{z}$ wizji Ezechiela skłania do zaczerpnięcia i wykorzystania na tym miejscu motywów innej wizji tegoż proroka. Oto Bóg wręcza mu zapisany zwój księgi i poleca go zjeść. Następnie posyła go do Izraelitów z misją przekazania im Jego słów (Ez 2, 7-3, 11). Człowiek, który zostaje przez Boga wybrany i przeznaczony do trudnej funkcji przemawiania do innych ludzi w Jego imieniu, musi - dosłownie - karmić się słowem Bożym („zjedz ten zwój i idź przemawiać” Ez 3,1) i żyć nim („weź sobie do serca wszystkie te słowa, które wyrzekłem do ciebie", Ez ,10). Sobór Watykański II mówi nawet wprost o stole słowa Bożego, z którego „Kościół nie przestaje brać i podawać wiernym chleb żywota” będącego „pokarmem dla duszy”36. Chodzi bowiem o takie dogłębne poznanie objawionej myśli i woli Bożej, aby je bezbłędnie i bez uszczerbku przekazać. Bóg chce nas zbawić i tę prawdę głosi Kościół ewangelizując cały świat.

Chrześcijanin przez sakrament chrztu staje się uczestnikiem prorockiej misji Chrystusa i przyjmuje na siebie obowiązek głoszenia Jego Ewangelii (OCHWD 224). Obrzęd wręczenia katechumenom księgi Ewangelii można zatem zinterpretować w świetle widzenia Ezechielowego jako wezwanie do dokładnego poznania osoby i nauki Jezusa Chrystusa również w celach apostolskich. Aspekt ewangelizacyjny obrzędu w tym kontekście jest bardzo czytelny.

Również ewangelijna scena, w której Jezus oddaje zwój księgi po przeczytaniu proroctwa Izajasza w synagodze nazaretańskiej (Łk 4, 20), stała się dla niektórych autorów inspirująca do wyrażenia myśli, że obrzęd przekazania Ewangelii był aluzją do tego właśnie gestu: Chrystus daje, wręcza księgę słowa Bożego ${ }^{37}$. Myśl ta nabiera sugestywności, gdy weźmie się pod uwagę szczegół o mesjańskim charakterze wspomnianego proroctwa (por. Iz 61, 1-2).

Po tym objaśniającym wstępie diakoni odczytywali kolejno początki wszystkich czterech Ewangelii, których wysłuchiwano w milczeniu i w postawie stojącej. Czytania były przeplatane wyjaśnianiem danego fragmentu, podawanym przez celebransa, przy czym nawiązywał on do owych symbolicznych postaci z proroctwa Ezechiela $^{38}$.

${ }^{35}$ M. R i g h e t t i, op. cit., s. 78; R. B é r a u d y, op. cit., s. 534; B. M ok r z y c k i, op. cit., s. 183 .

${ }^{36}$ Dei Verbum 21; Lumen Gentium 51.

${ }^{37} \mathrm{M}$. R i g h e t t i, op. cit., s. 78, przypis 130.

${ }^{38}$ Ibidem, s. 78; B. M o k r z y c k i, op. cit., s. 184. 
Dziś obrzęd wręczania Ewangelii odbywa się - jak dawniej podczas liturgii mszalnej. Wówczas jednak cały ryt przekazania mieścił się w ramach tej części, jaką było czytanie Ewangelii. Aktualnie wręczenie jest aktem, następującym po objaśniającej słowo Boże homilii. Katechumenom należy przede wszystkim ukazać godność głoszonego i słuchanego w Kościele słowa Bożego, do którego muszą odnosić się z należytą powagą i szacunkiem (OCHWD 91).

Kraków

Ks. SZYMON FEDOROWICZ

\section{Ks. Jerzy Chmiel}

\section{CAKUN TURYŃSKI ANNO DOMINI 1998}

W dniach od 18 kwietnia do 14 czerwca 1998 r. ma zostać wystawiony na widok publiczny w Turynie Całun (Ostensione della Sindone). W ostatnich czterech wiekach Całun był kilkakrotnie wystawiany; ostatnia ekspozycja publiczna miała miejsce przed dwudziestu laty, w roku 1978, z okazji 400-lecia przywiezienia płótna do Turynu. Tegoroczna ekspozycja wiąże się ze stuleciem rozpoczęcia systematycznych badań naukowych nad Całunem: 28 maja 1898 r. adwokat turyński Secondo Pia wykonał pierwsze fotografie Płótna, które w jakiś sposób zapoczątkowały rozwój interdyscyplinarnej wiedzy o Całunie, zwanej syndonologią. W związku z Ostensione 1998 został zaplanowany przez Centro Internazionale di Sindonologia w Turynie III Międzynarodowy Kongres Studiów nad Całunem (5-7 czerwca 1998 r.). Na czele komitetu organizacyjnego kongresu stoi znany syndonolog prof. P.L. Baima Bollone.

Czytelnicy polscy mieli okazję zapoznać się z historią i badaniami nad Całunem Turyńskim zarówno z przekładów literatury zagranicznej, jak i z polskich prac ${ }^{1}$. Prace nad Całunem są kontynuowane,

${ }^{1} \mathrm{Z}$ publikacji książkowych należy wymienić: R. H y n e k, Święty Całun $z$ Turynu. Męka Pańska w oświetleniu nauki, przel. St. Karwowski, Księgarnia Św. Wojciecha, Poznań 1937, ${ }^{2} 1938$; I. W i l s o n, Całun Turyński (3 różne przekłady polskie w 3 wydawnictwach); S. W a l i s z e w s k i, Catun Turyński dzisiaj, Wyd. WAM, Kraków 1987, ${ }^{2} 1991,{ }^{3} 1994 ;$ Z. Z i ó 1k ow s k i, Spór o Całun Turyński. Relikwia Męki Pańskiej w świetle najnowszych badan naukowych, Of. Wyd. „Adam”, Warszawa 1993 (obszerna bibliografia zagraniczna i polska); O. Petrosillo - E. Marinelli, Całun Turyński, relikwia czy falsyfikat? Krytyka ostatniego datowania, Wyd. Ks. Maria- 